\title{
A Research on Relationship between the Stock Holdings of Institutional Investors and the Stock Price Synchronicity of SME Board Market
}

\author{
Xiaohang Li \\ School of Economies, Jinan University, Guangzhou, China \\ Email: 704804311@qq.com
}

How to cite this paper: Li, X.H. (2017) A Research on Relationship between the Stock Holdings of Institutional Investors and the Stock Price Synchronicity of SME Board Market. Technology and Investment, 8, 1-10. https://doi.org/10.4236/ti.2017.81001

Received: December 16, 2016

Accepted: January 6, 2017

Published: January 9, 2017

Copyright $\odot 2017$ by author and Scientific Research Publishing Inc. This work is licensed under the Creative Commons Attribution International License (CC BY 4.0).

http://creativecommons.org/licenses/by/4.0/

\begin{abstract}
This paper uses the factor regression model of stock returns to quantify the stock price synchronization. Using the data of the listed companies in the Shenzhen SME board market from 2011 to 2015, this paper demonstrates the relationship of the stock holdings of institutional investors, the dummy variables of long- and short-term holdings and the proxy variable of the stock price of listed companies in the SME board. The conclusion is that the relationship between shareholding ratio of institutional investors and stock price synchronicity is an inverted U-shape. It means that in China when institutional investors hold less than a certain percentage, the shareholding proportion positively correlates with stock price synchronization. When institutional investors hold more than a certain percentage, the proportion of shareholding negatively correlates with stock price synchronization. The relationship between the stock holdings of institutional investors and stock price synchronization is also related to the type of institutional investors' holding behavior. The long-term stock holding behavior of institutional investors will decrease the stock price synchronization. The short-term stock holding behavior of institutional investors will improve the stock price synchronization.
\end{abstract}

\section{Keywords}

SME Board Market, Institutional Investors, Stock Price Synchronicity

\section{Introduction}

China's stock market has developed for nearly twenty-five years. There is no doubt that we have made remarkable achievements. However, due to various reasons, the market mechanism is so inadequate that the stock market of China has shown characteristics that the mature capital markets of other countries 
don't have. Through empirical analysis of the stock price index of the Shanghai Stock Exchange and the Shenzhen Stock Exchange, Qiao Yu [1] (1994) drew a conclusion that the reason of the cyclical abnormal returns of China's stock market and the fluctuation of stock prices is that the Chinese stock market is not efficient. Chengying He [2] (2001) proved that there is a plate phenomenon of stock price in the stock market of China. Peng Chen and Yicun Zheng [3] (2006) discussed the manifestation of plate linkage phenomenon, and conducted a cointegration test on the plate linkage phenomenon of the stock market in China. The results are that the plate linkage phenomenon has a period character. Institutional investors mainly refer to some financial institutions including banks, brokers, investment companies and so on. Compared with individual investors, they have capital strength, risk tolerance and professional trading capability. Their ability to obtain and interpret information is so strong that they play an important role in the stability of stock price. The research of Shixi Luo and Fu Cao [4] (1994) showed that the holding behavior of institutional investors can firstly gather social idle funds to expand the social demand for securities and promote the development of China's capital market. Secondly, the holding behavior of institutional investors is of great significance to reduce the stock price synchronicity and promote the stable development of the capital market. Thirdly, it is conducive to resolve the situation of the segmentation of corporation stock market and individual stock market. Finally, institutional investors entering capital market will contribute to the promotion of innovation activities in the capital market. Xuejun Fan [5] (1998) proposed the conclusion in his study that through a large number of long-term holding and active participation in corporate governance, institutional investors can eliminate the short-term pressure from capital markets. It is conducive to the long-term development of enterprises and can improve the competitiveness of enterprises. Hun Wang and Xing Xiao [6] (2005) researched the relationship between institutional investors and related parties occupying the capital. The result shows that China's institutional investors actively participate in corporate governance, play a certain role in the supervision, maintain the stability of the capital market effectively and decrease stock price synchronization. The study of Mozhu Yang [7] (2008) showed that the investment behavior of institutional investors in China's securities market tends to be value investment and long-term investment. The participation of institutional investors can improve the price fixing efficiency and stabilize the stock market.

Since the establishment of Shenzhen SME board market, there are more than 10 years of history. The study of SME board market is not as deep as Main board market. Compared to the GEM market, the development of SME board market is more mature and the degree of marketization is higher. Compared to the NEEQ, the pricing mechanism of the SME board is more perfect. The shareholding ratio of institutional investors in the SME board is also increasing year by year. Therefore, the combination of institutional investors and the SME board market plays an important role in further standardizing the investment behavior 
of institutional investors and promoting the healthy development of listed companies.

This paper empirically studies the impact of the stock holdings of institutional investors on the synchronization of stock price in Shenzhen SME board market, empirically analyses the long-term and short-term stock holding behavior of institutional investors and researches whether institutional investors have a stake in the long-term or short-term holdings has an influence on stock price synchronicity. The result shows that the relationship between institutional investors' shareholding ratio and stock price synchronization is an inverted U-shape. When the ratio is less than a certain percentage, the cost of participating in the management of the enterprise is higher than the profit. Institutional investors tend to take a negative attitude towards corporate management, which cannot make the stock price of listed companies reflect more fundamentals of the enterprise. This will lead to a positive correlation between the shareholding ratio and the stock price synchronization. When the ratio is more than a certain percentage, the profit of participating in the management of the enterprise is higher than the cost, so institutional investors participate in corporate management with a positive attitude. The relationship between the stock holdings of institutional investors and stock price synchronization is related to the category of institutional investors' stock holding behavior. According to the length of time that institutional investors holding a stock, the holding behavior of institutional investors will be divided into speculation behavior (holding less than a year) and value investing behavior (holding more than one year). After verifying the effect of the two kinds of behavior on stock price synchronization, the conclusion is drawn. The long-term holding behavior of institutional investors will weaken the stock price synchronicity of SME board market, while the short-term holding behavior of institutional investors will improve the stock price synchronization of SME board market.

\section{Research Hypothesis}

\subsection{Hypothesis 1}

When the shareholding ratio of institutional investors is less than a certain proportion, the cost of enterprise management is higher than the benefit, so institutional investors have a negative attitude about participating in the management, and even use the stock price synchronicity to obtain benefits. Therefore it cannot make the stock price reflect fundamentals of listed companies. In such a situation, the shareholding ratio is positively correlated with stock price synchronicity. When the shareholding ratio of institutional investors is more than a certain proportion, the benefit of participating in corporate governance is higher than the cost and the institutional investors hold a positive attitude to participate in enterprise management. In this situation, the shareholding ratio is negatively correlated with stock price synchronicity. Based on this, it puts forward the hypothesis 1.

H1: When institutional investors hold less than a certain percentage, the 
shareholding proportion positively correlates with stock price synchronization. When institutional investors hold more than a certain percentage, the proportion of shareholding negatively correlates with stock price synchronization.

\subsection{Hypothesis 2}

The existence of noise in the financial market can result in the price of stock market seriously deviate from its intrinsic value. The study of Yaping Wang, Huilong Liu and Liansheng $\mathrm{Wu}$ [8] (2009) shows that in the financial market with less noise, the higher the information transparency is, the more individual information the stock price contains. So stock price synchronization is negatively correlated with information transparency. For the financial market with more noise, the increasing of information disclosure will make the stock price uncertainty weakened, so that the stock price synchronization and information transparency are positively correlated. Because the SME board market is the capital market with a high degree of marketization, the stock price synchronization is negatively correlated with the information transparency. Long-term investment behavior is the value investment behavior. In this paper, it is the behavior that the institutional investors hold the stock more than one year. Short-term investment behavior is speculation. This paper refers to the behavior that the institutional investors hold the stock less than one year. The value investment behavior of institutional investors will increase the transparency of information and decrease the stock price synchronization. Speculation will decrease the stock information that the stock price reflects, and thus increase the stock price synchronization. Based on this, it puts forward the hypothesis 2 .

$\mathrm{H} 2$ : The long-term stock holding behavior of institutional investors will decrease the stock price synchronization. The short-term stock holding behavior of institutional investors will improve the stock price synchronization.

\section{Study Design}

\subsection{Quantification of Stock Price Synchronization}

The stock price synchronization measures the correlation between individual stock price and the average price of the stock market. when the stock prices rise and fall together significantly, the correlation between individual stock price and the average price is high, and the synchronization of stock price is high. In this paper, the measurement of stock price synchronicity in SME board market is as same as the measurement used by many domestic researches. The paper uses the $R^{2}$ which is obtained by the factor regression model of stock returns to replace the stock price synchronicity. This paper uses the model that considers the market revenue and the industry factors to measure $R^{2}$ :

$$
r_{i t}=\alpha_{i}+\beta_{i} r_{m t}+\gamma_{i} r_{j t}+\varepsilon_{i t}(t=1,2, \cdots, n)
$$

The $r_{i t}$ is the return rate of stock $i$ at time $t$. The $r_{m t}$ is the return rate of the market at time $t$. The $r_{j t}$ is the industry return rate of industry $j$ that the stock $i$ belongs to. The $\varepsilon_{i t}$ is the stochastic disturbance term. 
This paper used the individual stock return rate as the explained variable, used the industry return rate and the market return rate as explanatory variables. $\mathrm{R}$-square which is obtained by regression can represent the stock price synchronicity. The higher the value of the R-square is, the higher the degree of fitting is. The correlation between individual stock return rate and the return rate of market and industry is greater. The phenomenon of the stock prices rise and fall together is more obvious and the stock price synchronization is stronger.

\subsection{Setting of Correlation Variables of Institutional Investors}

The paper focuses on the relationship between the stock holdings of institutional investors and the stock price synchronicity of SME board market. If the institutional investors hold a stock less than $1 \%$, it is considered that the stock is not held by the institutional investors. If a stock is held by institutional investors for less than one year, it is defined as a speculative investment behavior. And if a stock is held by institutional investors for more than one year, it is known as long-term holding behavior.

\subsection{Setting of Control Variables}

Some characteristic variables such as the size of the company, the stock turnover rate, the book market ratio, the asset liability ratio, the equity concentration, the age of company may affect the stock price synchronization.

\subsection{Sample Selection}

Since 2011, China's economic climate has not fundamentally changed. Since 2009, China has been adopting a proactive fiscal policy and a prudent monetary policy. As far as China's economic situation is concerned, this policy is sustainable. Therefore, the issue of economic stabilization has not changed, so it can be predicted by analyzing the past five years. From 2011 to 2015, China's capital market experienced bull market, bear market and long-term shocking market. Therefore, taking this period as the research object could offset the error caused by researching under a certain market. So this paper used panel data of listed companies in the SME board market from 2011 to 2015 as a primary sample, and removed some original data with the following principles:

1) Excluding the listed companies in the financial industry.

2) Excluding the newly listed company.

3) Excluding all ST and ${ }^{*}$ ST listed companies.

4) Excluding the listed companies that the data is incomplete.

The sample data comes from the WIND database. The definitions of variables can be seen in Table 1 .

\subsection{Setting of Regression Model}

This paper aims to examine the relationship of the institutional investor shareholding ratio, the type of stock holding behavior and the stock price synchronization. So the following regression models are set up: 
Table 1. Variable definition table.

\begin{tabular}{|c|c|c|c|}
\hline & Variable Name & Symbol & Variable Definition \\
\hline Explained Variable & Stock Price Synchronicity & $S Y N C H$ & $\operatorname{Ln}\left(R^{2} /\left(1-R^{2}\right)\right)$ \\
\hline \multirow[t]{4}{*}{ Explanatory Variable } & $\begin{array}{l}\text { Dummy Variable of Institutional } \\
\text { Investors Holding }\end{array}$ & DUM & $\begin{array}{l}\text { If there is institutional investors holding, it is } 1 \text {, otherwise } \\
\text { it is } 0 .\end{array}$ \\
\hline & $\begin{array}{l}\text { Dummy Variable of Institutional } \\
\text { Investors Long-term Holding }\end{array}$ & $H O L D L$ & $\begin{array}{l}\text { If there is institutional investors long-term holding, it is } 1 \text {, } \\
\text { otherwise it is } 0 .\end{array}$ \\
\hline & $\begin{array}{l}\text { Dummy Variable of Institutional } \\
\text { Investors Short-term Holding }\end{array}$ & HOLDS & $\begin{array}{l}\text { If there is institutional investors short-term holding, it is } 1 \text {, } \\
\text { otherwise it is } 0 .\end{array}$ \\
\hline & $\begin{array}{l}\text { Shareholding Ratio of Institutional } \\
\text { Investors }\end{array}$ & IS & Data comes from the WIND database. \\
\hline \multirow[t]{7}{*}{ Controlled Variable } & Turnover Rate & TURNO & The average turnover rate in the quarter. \\
\hline & Company Size & $T A$ & $\ln$ (year-end total assets). \\
\hline & $\begin{array}{l}\text { Rate of Return on Common Stockholders' } \\
\text { Equity }\end{array}$ & $R O E$ & Data comes from the WIND database. \\
\hline & Corporate Capital Structure & $L E V$ & $\begin{array}{l}\text { The date of asset-liability ratio comes from the WIND } \\
\text { database. }\end{array}$ \\
\hline & Book-to-Market & $B M$ & total assets/circulation market value. \\
\hline & Company Age & $A G E$ & $\ln (1+$ corporate life $)$ \\
\hline & $\begin{array}{l}\text { The Proportion of the First Largest } \\
\text { Shareholder }\end{array}$ & TOP1 & Quarterly data comes from the WIND database. \\
\hline
\end{tabular}

$$
\begin{aligned}
\text { SYNCH }= & \alpha_{0}+\alpha_{1} I S_{2}+\alpha_{2} I S+\alpha_{3} D U M+\alpha_{4} T U R N O+\alpha_{5} T A+\alpha_{6} R O E \\
& +\alpha_{7} L E V+\alpha_{8} B M+\alpha_{9} A G E+\varepsilon(\text { Used for testing } H 1) \\
S Y N C H= & \beta_{0}+\beta_{1} H O L D S+\beta_{2} H O L D L+\beta_{3} T U R N O+\beta_{4} T A+\beta_{5} R O E+\beta_{6} L E V \\
& +\beta_{7} B M+\beta_{8} A G E+\beta_{9} T O P 1+\varepsilon(\text { Used for testing } H 2)
\end{aligned}
$$

\section{Empirical Process and Analysis}

\subsection{Relationship between Shareholding Ratio and Stock Price Synchronization}

This paper firstly studies the influence of whether there are stock holdings of institutional investors and the shareholding ratio on stock price synchronization. Through the regression of the DUM dummy variable, and controlling variables that affect the stock price synchronization, conclusions can be drawn. The results are shown in Table 2.

In the model, the square of the shareholding ratio of institutional investors is negatively correlated with the stock price synchronization in the significant level of 0.01 . The coefficient of institutional investors' shareholding ratio is positive. This indicates that the relationship between the shareholding ratio of institutional investors and stock price synchronization is an inverted U-shape, which proves the hypothesis 1 . It can be calculated that when IS $=0.0702$, the stock price synchronization has the maximum value. It shows that $7.02 \%$ of the proportion is the dividing line that whether the stock holdings of institutional in- 
Table 2. Relationship between shareholding ratio and stock price synchronization.

\begin{tabular}{cccc}
\hline Variables & Coefficient & Standard Deviation & t-Value \\
\hline IS & $-0.6233^{* * *}$ & 0.1912 & -3.26 \\
IS & 0.0875 & 0.1524 & 0.57 \\
DUM & $-0.1108^{*}$ & 0.0572 & -1.94 \\
TURNO & $-0.1473^{* * *}$ & 0.0107 & -13.79 \\
TA & -0.0039 & 0.0143 & -0.27 \\
ROE & 0.2213 & 0.3568 & 0.62 \\
LEV & $-0.3405^{* * *}$ & 0.0585 & -5.82 \\
BM & $-6.1417^{* * *}$ & 0.4527 & -13.57 \\
AGE & $0.1164^{* *}$ & 0.0463 & 2.52 \\
Constant & -0.1067 & 0.3408 & -0.31 \\
Observations: 6642 & & & \\
Number of season: 18 & & & \\
R-squared: 0.070 & & & \\
\hline
\end{tabular}

vestors can reduce the stock price synchronization of the SME board market. When the shareholding ratio of institutional investors is less than $7.02 \%$, the cost of enterprise management is higher than the benefit, so institutional investors have a negative attitude about participating in the management, and even use the stock price synchronicity to obtain benefits. Therefore it cannot make the stock price reflect fundamentals of listed companies. When the shareholding ratio of institutional investors is more than $7.02 \%$, the benefit of participating in corporate governance is higher than the cost and the institutional investors hold a positive attitude to participate in enterprise management.

\subsection{Relationship between Shareholding Behavior and Stock Price Synchronization}

In this paper, the shareholding behavior of institutional investors is divided into short-term speculative behavior and long-term value investment behavior. The impact of different investment behavior on the synchronization of stock price is investigated. The results are shown in Table 3.

In the model, short-term holding behavior of institutional investors and stock price synchronicity are positively related in the 0.01 significant level and the coefficient of short-term holding behavior of institutional investors is positive, which indicates that the short-term holding behavior of institutional investors will increase the stock price synchronicity. Long-term holding behavior of institutional investors and stock price synchronicity are negatively related in the 0.01 significant level and the coefficient of long-term holding behavior of institutional investors is negatively, which indicates that the long-term holding behavior of institutional investors will decrease the stock price synchronicity. It is consistent with the expected results. Turnover rate is negatively related with stock price synchronicity. According to the research of Menggen Chen and Xiaoyuan Mao 
Table 3. Relationship between shareholding behavior and stock price synchronization.

\begin{tabular}{cccc}
\hline Variables & Coefficient & Standard Deviation & t-Value \\
\hline HOLDS & $0.9552^{* * *}$ & 0.0182 & 52.48 \\
HOLDL & $-0.8579^{* * *}$ & 0.0319 & -26.86 \\
TURNO & $-0.0717^{* * *}$ & 0.0083 & -8.62 \\
TA & $-0.1240^{* * *}$ & 0.0120 & -10.30 \\
ROE & -0.0838 & 0.2939 & -0.29 \\
LEV & $-0.2356^{* * *}$ & 0.0483 & -4.88 \\
BM & $-3.6434^{* * *}$ & 0.3742 & -9.74 \\
AGE & 0.0428 & 0.0385 & 1.11 \\
TOP1 & $-0.4173^{* * *}$ & 0.0553 & -7.55 \\
Constant & $2.6235^{* * *}$ & 0.2834 & 9.26 \\
Observations: 6642 & & & \\
Number of season: 18 & & & \\
R-squared: 0.875 & & & \\
\hline
\end{tabular}

[9] (2007), the active degree of stock trading in the Chinese stock market has a positive correlation with the information content of the stock price. If the stock price contains more information, the stock price volatility and the company's fundamentals are more closely related, then the investor's enthusiasm for the stock trading is higher and the market transactions will be more active. The coefficient of company size is significantly negative. It means that compared with small companies, large companies have better corporate governance structure and the price includes more basic information of the company, so the stock price synchronicity is lower. The relationship between asset-liability ratio and stock price synchronicity is negative, which is consistent with our expectations. In addition, the higher the proportion of the first major shareholder of the company is, the lower the stock price synchronicity is.

\section{Conclusion and Enlightenment}

This paper researches the influence of institutional investors' shareholding ratio and different stock holding behavior on the stock price synchronization in the Shenzhen SME board market by setting the nonlinear regression. Firstly, the paper investigated the influence of different institutional investors' shareholding ratio on stock price synchronization. After that, the article classified the investment behavior of institutional investors according to the length of the holding period to analyze the impact of long-term value investment behavior and shortterm speculative behavior of institutional investors on stock price synchronization. Through the research, this paper mainly draws the following conclusions:

1) The relationship between shareholding ratio of institutional investors and stock price synchronicity of Shenzhen SME board market is an inverted Ushape. When the shareholding ratio of institutional investors is less than $7.02 \%$, the shareholding ratio and stock price synchronicity are positively correlated. 
When the shareholding ratio of institutional investors is more than $7.02 \%$, the shareholding ratio and stock price synchronicity are negatively correlated.

2) The value investment behavior of institutional investors can effectively reduce the stock price synchronicity of Shenzhen SME board market, while the speculation will increase the stock price synchronization.

These conclusions are of great significance for China's stock market to give full play to institutional investors' supervisory role. First of all, it can be considered that is appropriating to relax the shareholding ratio restrictions of institutional investors in listed companies of Shenzhen SME board market and portfolio to strengthen the concept of long-term investment. Institutional investors will be more concerned about the long-term benefits of listed companies, rather than short-term performance. Secondly, it is important to improve the information disclosure quality and quantity of institutional investors in Shenzhen SME board market especially changes of the portfolio, and set a certain limit on institutional investors' turnover rate to increase transaction price pressures and liquidity constraints which can restrict institutional investors to pursue shortterm interests. Thirdly, it is imperative to strengthen the legal system construction of China's stock market, strengthen the capital market supervision and reduce the opportunism speculative behavior of institutional investors. At last, this study has some reference value for other capital markets such as India and some country of Europe of which the capital market development degree is similar as China's capital market.

\section{Acknowledgements}

In completion of this paper, I want to thank my tutor Liu Shaobo first. During my three years as a graduate student, he gave me a lot of help in my studies and employment. He gave me a lot of advice when I wrote the article. I would like to thank Professor Liu for his careful guidance. Meanwhile, I would also like to thank my parents and family, my school and my roommates for creating a good learning environment for me so that I can finish my thesis in a good atmosphere.

\section{References}

[1] Yu, Q. (1994) Market Efficiency, Cycle Anomaly and Stock Price Volatility-An Empirical Analysis of Stock Market in Shanghai and Shenzhen. Economic Research Journal, 9, 43-50.

[2] He, C.Y. (2001) Analysis of "Plate Phenomenon" in Chinese Stock Market. Economic Research Journal, 12, 82-87.

[3] Chen, P. and Zheng, Y.C. (2006) Analysis of "Plate Linkage" Phenomenon in Chinese Stock Market. Times Finance, 20, 31-32.

[4] Luo, S.X. and Cao, F. (1994) Institutional Investors and the Development of Capital Market. Journal of Peking University, 4, 69-77.

[5] Fan, X.J. (1998) The Role of Institutional Investors in Corporate Governance. Shanghai Journal of Economics, 1, 52-55.

[6] Wang, K. and Xiao, X. (2005) The Empirical Study on the Institutional Ownership 
and Resources Expropriation by the Related Parties. Nankai Business Review, 2, 27 33.

[7] Yang, M.Z. (2008) Analysis on Investment Behavior of Institutional Investors in Securities Market. Journal of Financial Research, 8, 133-144.

[8] Wang, Y.P., Liu, H.L. and Wu, L.S. (2009) Information Transparency, Institutional Investors and Stock Price Synchronicity. Journal of Financial Research, 12, 162-174.

[9] Chen, M.G. and Mao, X.Y. (2007) Stock Price Information Content and Market Transaction Activity. Journal of Financial Research, 3, 125-139.

Submit or recommend next manuscript to SCIRP and we will provide best service for you:

Accepting pre-submission inquiries through Email, Facebook, LinkedIn, Twitter, etc. A wide selection of journals (inclusive of 9 subjects, more than 200 journals) Providing 24-hour high-quality service User-friendly online submission system Fair and swift peer-review system Efficient typesetting and proofreading procedure Display of the result of downloads and visits, as well as the number of cited articles Maximum dissemination of your research work

Submit your manuscript at: http://papersubmission.scirp.org/

Or contact ti@scirp.org 